\title{
The immunomodulatory activity of ethanol extract of attarasa bark and fruit (Litsea cubeba (lour.) pers.) toward carbon clearance of mice (Mus musculus)
}

\section{Aktivitas imunomodulator ekstrak etanol kulit batang dan buah attarasa (Litsea cubeba (lour.) pers.) terhadap klirens karbon mencit (Mus musculus)}

\author{
Vivi Asfianti ${ }^{1 *}$, Alfi Sapitri ${ }^{1}$, Eva Diansari Marbun ${ }^{1}$ \\ ${ }^{1}$ Fakultas Farmasi dan Ilmu Kesehatan, Universitas Sari Mutiara Indonesia, Medan, Indonesia \\ *Corresponding author: vivi.asfianti@yahoo.com
}

\begin{abstract}
Background: Attarasa (L.a cubeba (Lour.) Pers.) is a potential Indonesian medicinal plant that is used as a cold remedy, head ulcers, antimicrobials, antioxidants, and anticancer drugs.

Objective: This research was conducted to analyze the immunomodulatory effect of bark (EEKBA) and fruit of attarasa ethanolic extract (EEBA) by detecting its phagocytosis activity in male mice using carbon clearance method.

Method: Total of 24 male mice were divided into 6 groups. Extract was orally administered to mices for 7 days at the dose of $100 \mathrm{mg} / \mathrm{kg} \mathrm{BW}, 200 \mathrm{mg} / \mathrm{kg} \mathrm{BW}$, and $400 \mathrm{mg} / \mathrm{kg} \mathrm{BW}$. Imboost ${ }^{\circledR}$ suspension at the dose of $32.5 \mathrm{mg} / \mathrm{kg}$ BW and CMC-Na $1 \%$ suspension was orally administered in positive control, negative control and normal groups. On the $8^{\text {th }}$ day, $0.1 \mathrm{ml}$ carbon suspension was given through intravenous tail injection. The blood samples were withdrawn at 5, 10, 15, and 20 minutes after injection of carbon suspension to find out the carbon absorbance contained in the blood that was measured using spectrophotometer then the carbon elimination speed, phagocytic index, and the stimulation index has been calculated

Result: EEKBA and EEBA at the dose of $400 \mathrm{mg} / \mathrm{kg}$ BW induced the higher carbon elimination rate in mice compared to EEKBA and EEBA dose of 100 and $200 \mathrm{mg} / \mathrm{kg}$ BW. Phagocytic index of macrophage in mice given with EEKBA and EEBA at dose of 100, 200, dan $400 \mathrm{mg} / \mathrm{kg}$ BW were 3.429, 3.501, and 3.925 for EEKBA consecutively; 4.289, 4.375 and 4.732 for EEBA respectively. Stimulation index of macrophage in mice given with EEKBA and EEBA at dose of 100, 200, and $400 \mathrm{mg} / \mathrm{kg} \mathrm{BW}$ were 1.00; 1.20, 1,02; 1,23, and 1,$13 ; 1,33$. Based on the results of statistical test, EEKBA and EEBA administration at the dose of 100, 200, and $400 \mathrm{mg} / \mathrm{kg}$ BW stimulate the phagocytosis activity of the macrophage of male mice and significantly has different result compared to normal control group $(\mathrm{p}<0.05)$. Phagocytosis activity was best shown at the mice group that administered EEKBA and EEBA at dose of $400 \mathrm{mg} / \mathrm{kg}$ BW and was shown not significantly different compared to positive control group ( $\mathrm{p}>0.05)$.
\end{abstract}

Conclusion: EEKBA and EEBA have immunomodulatory effect by increasing the phagocytosis activity of mice.

Keywords: immunomodulatory, Litsea cubeba, carbon clearance, phagocytosis activity

\section{Intisari}

Latar belakang: Attarasa (Litsea cubeba (Lour.) Pers.) merupakan tumbuhan obat potensial Indonesia yang digunakan sebagai obat flu, borok dikepala, antimikroba, antioksidan dan antikanker.

Tujuan: Penelitian ini dilakukan untuk dapat mengamati efek imunomodulator Ekstrak Etanol Kulit Batang (EEKBA) dan Ekstrak Etanol Buah Attarasa (EEBA) terhadap aktivitas fagositosis pada mencit jantan dengan menggunakan metode carbon clearance.

Metode: Sebanyak 24 ekor mencit jantan dibagi menjadi 6 kelompok. Ekstrak diberikan secara per oral selama 7 hari pada mencit jantan dengan dosis 100 , 200, dan $400 \mathrm{mg} / \mathrm{kg}$ BB. Suspensi imboost ${ }^{\circledR}$ dengan dosis 32,5 mg/kg BB, suspensi CMC-Na 1\% diberikan pada kelompok kontrol positif, negatif, dan normal. Pada hari ke-8 disuntikkan suspensi karbon 0,1 ml secara intravena di ekor mencit. Sampel darah dikumpulkan pada menit ke-5, 10, 15, dan 20 setelah diinjeksi dengan suspensi karbon untuk mengetahui 
absorbansi karbon dalam darah yang diukur menggunakan spektrofotometer kemudian dihitung kecepatan eliminasi karbon, indeks fagositosis, dan indeks stimulasinya.

Hasil: EEKBA and EEBA dosis $400 \mathrm{mg} / \mathrm{kg}$ BB menghasilkan kecepatan eliminasi karbon yang paling tinggi dibandingkan dengan EEAB dan EEAF 100 dan $200 \mathrm{mg} / \mathrm{kg}$ BB. Indeks fagositosis yang dihasilkan dari pemejanan EEKBA and EEBA dosis 100, 200, dan $400 \mathrm{mg} / \mathrm{kg}$ BB terhadap hewan uji yaitu 3,429; 4,289; 3,501; 4,375 dan 3,925; 4,732. Indeks stimulasi makrofag yang diperoleh setelah hewan uji dipejani dengan EEKBA and EEBA dosis 100, 200, dan $400 \mathrm{mg} / \mathrm{kg}$ BB yaitu 1,00; 1,20, 1,02; 1,23, dan 1,13; 1,33. Berdasarkan hasil uji statistik, pemberian EEKBA and EEBA pada dosis 100, 200, dan $400 \mathrm{mg} / \mathrm{kg}$ BB dapat meningkatkan aktivitas fagositosis pada mencit jantan dan terdapat perbedaan yang signifikan dengan CMC-Na $1 \%$ dan kelompok normal $(\mathrm{p}<0,05)$. Aktivitas fagositosis yang paling baik ditemukan pada pemberian EEKBA and EEBA dengan dosis $400 \mathrm{mg} / \mathrm{kg}$ BB dengan perbedaan yang tidak signifikan terhadap kelompok hewan uji yang diberi $\operatorname{Imboost}^{\circledR}(p>0,05)$.

Kesimpulan: EEKBA and EEBA mempunyai efek imunomodulator dengan meningkatkan aktivitas fagositosis pada mencit jantan

Kata kunci: imunomodulator, Litsea cubeba, carbon clearance, aktivitas fagositosis.

\section{Pendahuluan}

Tubuh manusia telah dilengkapi dengan sistem pertahanan yang sangat kompleks untuk menjaganya agar tetap sehat, yang dikenal dengan istilah imun. Imunitas dapat didefinisikan sebagai pertahanan terhadap penyakit, utamanya penyakit yang disebabkan karena infeksi. Sementara itu, sistem imun adalah gabungan antara sel, jaringan, dan molekul yang memerantai pertahanan terhadap infeksi (Sasmito, 2017).

Sediaan farmasi yang memiliki aktivitas sebagai imunomodulator menjadi sangat populer di lingkup industri obat bahan alam ketika masyarakat menyadari peran penting sistem imun dalam mencegah dan membantu pemulihan penyakit infeksi serta memelihara kesehatan (Sasmito, 2017). Namun demikian penggunaan imunomodulator dalam terapi dapat mengalami hambatan, salah satunya adalah mahalnya imunomodulator yang tersedia di pasar obat dalam bentuk paten dan mayoritas diimpor dari luar negeri. Dalam keadaan demikian, sangatlah perlu dipertimbangkan untuk memperoleh imunomodulator dari bahan alam agar faktor harga dapat ditekan (Rahman, dkk, 2016).

Tanaman attarasa adalah penghasil minyak atsiri yang bernilai ekonomis tinggi. Minyak atsiri attarasa dimanfaatkan sebagai bahan baku untuk kosmetika, sabun, minyak wangi, aromaterapi dan obat-obatan. Namun, kandungan minyak atsiri yang terbanyak terdapat pada kulit batang dibandingkan buahnya. Kulit batang attarasa mengandung saponin, flavonoid dan tanin (Kurniaty, dkk, 2014). Salah satu senyawa yang berpotensi sebagai agen imunomodulator adalah flavonoid. Kandungan senyawa antioksidan ekstrak etanol kulit batang dan buah attarasa berpotensi menghasilkan efek imunomodulator (Azizah, dkk, 2017).

Metode bersihan karbon (carbon clearance) merupakan pengukuran secara 
spektrofotometri laju eliminasi partikel karbon dari darah hewan. Metode ini dapat merepresentasikan aktivitas fagositosis (Linsentia, 2011).

\section{Metode}

\subsection{Bahan dan alat}

Dalam penelitian ini beberapa bahan yang digunakan antara lain: kulit batang dan buah attarasa, etanol p.a (Merck), akuades, tinta cina merk pelican B-17, CMC-Na, tablet imboost ${ }^{\circledR}$ (Soho), natrium sitrat $1 \%$, asam asetat $1 \%$, larutan $\mathrm{NaCl} 0,9 \%$.

\subsection{Identifikasi tumbuhan attarasa dan pembuatan ekstrak etanol kulit batang dan buah attarasa}

Sebelum proses ekstraksi dilakukan determinasi tanaman di Lembaga Ilmu Pengetahuan Indonesia (LIPI) Cibinong Science Center, Jl. Raya Jakarta - Bogor KM.46 Cibinong 16911. Ekstraksi dilakukan dengan maserasi. Sebanyak 500 gram serbuk simplisia dimasukkan ke dalam sebuah bejana, ditambahkan dengan 3750 etanol, kemudian ditutup dan dibiarkan selama 5 hari terlindung dari cahaya sambil dilakukan pengadukan beberapa kali. Setelah selesai maserasi, maserat dipisahkan dengan ampas. Dilakukan remaserasi kembali selama 2 hari. Maserat yang dihasilkan kemudian dikumpulkan dan diuapkan hingga dihasilkan ekstrak (Ditjen POM, 2000).

\subsection{Pembuatan suspensi karbon}

Pembuatan suspensi karbon dilakukan dengan cara mensuspensikan 1,6 $\mathrm{mL}$ tinta cina pelikan B-17 ke dalam 8,4 mL suspensi CMC Na 1\% dalam larutan fisiologis $\mathrm{NaCl} 0,9 \%$ (Faradilla dan Maria, 2014).

\subsection{Pembuatan suspensi ekstrak etanol kulit batang dan buah attarasa}

Sebanyak 1 gram ekstrak etanol kulit batang attarasa ditambahkan sedikit demi sedikit suspensi CMC Na 1\% hingga homogen. Setelah homogen, larutan dituangkan dalam labu ukur $100 \mathrm{~mL}$ dan dicukupkan dengan suspensi CMC Na 1\% hingga garis tanda hingga diperoleh konsentrasi ekstrak etanol kulit batang attarasa 1\% (Tambusai, 2018).

\subsection{Pengujian efek imunomodulator metode klirens karbon}

Uji efek imunomodulator ekstak etanol kulit batang dan buah Attarasa ditentukan menggunakan metode bersihan karbon dengan mengukur absorbansinya menggunakan spektrofotometer UV-Vis. Sejumlah 36 ekor mencit dibagi menjadi 9 kelompok dosis dengan rincian pemejanannya secara peroral satu kali sehari selama 7 hari sebagai berikut:

Kelompok 1 : tanpa pemejanan

Kelompok 2 : suspensi CMC-Na 1\%

Kelompok $3 \quad$ : Imboost $^{\circledR}$ dosis $32,5 \mathrm{mg} / \mathrm{kg} \mathrm{bb}$ 


$\begin{array}{ll}\text { Kelompok } 4 & \text { : EEKBA dosis } 100 \mathrm{mg} / \mathrm{kg} \text { bb } \\ \text { Kelompok } 5 & \text { : EEKBA dosis } 200 \mathrm{mg} / \mathrm{kg} \text { bb } \\ \text { Kelompok } 6 & \text { : EEKBA dosis } 400 \mathrm{mg} / \mathrm{kg} \mathrm{bb} \\ \text { Kelompok } 7 & \text { : EEBA dosis } 100 \mathrm{mg} / \mathrm{kg} \mathrm{bb} \\ \text { Kelompok } 8 & : \text { EEBA dosis } 200 \mathrm{mg} / \mathrm{kg} \mathrm{bb} \\ \text { Kelompok } 9 & : \text { EEBA dosis } 400 \mathrm{mg} / \mathrm{kg} \mathrm{bb}\end{array}$

Pada hari ke-8 setelah 7 hari pemberian suspensi sampel pada masing-masing kelompok, ujung ekor mencit dipotong kemudian darah ditampung dalam tabung yang telah diisi dengan Na-sitrat. Sebanyak $10 \mu \mathrm{l}$ darah ditambahkan $4 \mathrm{~mL}$ asam asetat 1\% untuk meliliskan sel darah merah kemudian diukur absorbansinya pada $632 \mathrm{~nm}$ menggunakan spektrofotometer. Sampel darah yang pertama kali diambil (menit ke-0) digunakan sebagai blanko. Sebesar 0,1 mL suspensi karbon disuntikkan secara intravena melalui pembuluh darah ekor, dan pada menit ke5, 10, 15 dan 20 setelah penyuntikan karbon, darah kembali ditampung kemudian dilakukan langkah yang sama seperti pada blanko. Setelah 12 jam diambil darahnya, kemudian hati dan limfa dicatat beratnya (Aldi, dkk., 2013). Setelah pengambilan darah pada ujung ekor mencit tersebut dihitung konstanta kecepatan eliminasi karbon $(\mathrm{K})$, indeks fagositosi $(\alpha)$ dan indeks stimulasi dengan menggunakan rumus:

$$
\begin{aligned}
\text { Konstanta kecepatan eliminasi karbon }(\mathrm{K}) & =\frac{\log O D 5-\log \text { OD } 20}{T_{2-T_{1}}} \\
& =\frac{k_{3 \times \text { berat hewan }}^{1}}{\text { berathati+berat limfa }} \\
& =\frac{\text { indeks fagositosis kelompok uji }}{\text { indeks fagositosis kelompok kontrol }}
\end{aligned}
$$

Keterangan:

$$
\begin{aligned}
\mathrm{OD}_{5} & =\text { absorbansi pada menit ke } 5 \\
\mathrm{OD}_{20} & =\text { absorbansi pada menit ke } 20 \\
\mathrm{~T}_{1} & =\text { waktu pertama pengambilan darah } \\
\mathrm{T}_{2} \quad= & \text { waktu terakhir pengambilan darah } \\
= & \text { Indeks fagositosis dan indeks stimulasi dari tiap kelompok uji dibandingkan dengan } \\
& \text { kelompok kontrol (Kala et al., 2015) }
\end{aligned}
$$

\section{Hasil dan pembahasaan}

3.1. Hasil ekstraksi kulit batang dan buah attarasa menggunakan pelarut etanol p.a dengan cara maserasi

Hasil determinasi menyatakan spesies yang digunakan adalah L. cubeba (Lour) Pers. 
Hasil penyarian serbuk simplisia kulit batang attarasa diperoleh ekstrak kental sebanyak 140 gram. Ekstraksi serbuk simplisia buah attarasa menghasilkan ekstrak kental sejumlah 150gram.

\subsection{Hasil uji efek imunomodulator ekstrak etanol kulit batang dan buah attarasa}

\subsubsection{Laju eliminasi karbon}

Pada penelitian ini dilakukan pengujian respon imun non spesifik dengan menggunakan metode bersihan karbon. Uji ini merupakan respon non spesifik unuk mengetahui aktivitas fagositosis sel makrofag terhadap karbon sebagai zat asing (Shukla, dkk., 2009). Karbon akan berkurang jumlahnya dalam darah seiring pertambahan waktu, karena adanya peristiwa fagositosis oleh sel-sel leukosit terutama neutrophil, monosit, dan makrofag. Laju eliminasi karbon merupakan suatu metode yang digunakan utuk mengukur aktivitas fagositosis pada mencit. Hasil laju eliminasi karbon dalam darah (EEBA dan EEFA) ditunjukkan pada Gambar 1.

\section{Laju eliminasi karbon (EEKBA)}
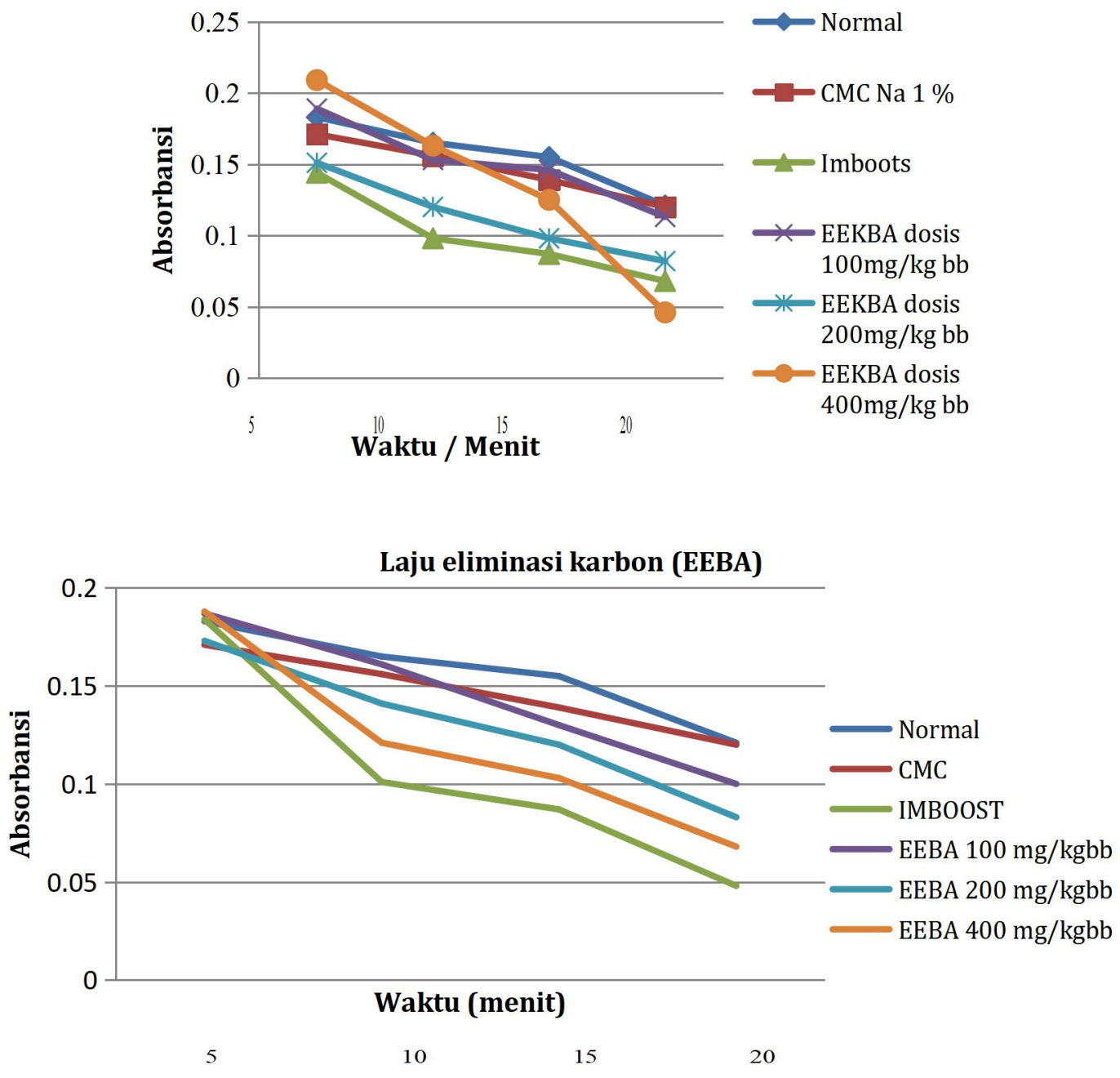

Gambar 1. Laju eliminasi karbon 
Pada Gambar 1 dapat dilihat nilai absorban panjang gelombang karbon dalam darah menurun tiap rentang waktu, berarti setiap konsentrasi ekstrak uji dapat memberikan efek imunostimulan. Penggunaan variasi konsentrasi ekstrak uji pada perlakuan ini untuk mengetahui hubungan antara peningkatan konsentrasi ekstrak uji dengan aktivitas penurunan karbon dalam darah. Pada Gambar 1 juga dapat dilihat adanya penurunan nilai absorban pada semua kelompok sediaan uji dibandingkan dengan kelompok kontrol negatif. Penurunan nilai absorban terbesar terdapat pada dosis $400 \mathrm{mg} / \mathrm{kg}$ bb, semakin menurunnya nilai absorban berarti konsentrasi karbon yang tinggal dalam darah mencit semakin sedikit. Hal ini memperlihatkan bahwa terjadi peningkatan aktivitas fagositosis pada masing-masing kelompok sediaan ekstrak uji. Penurunan nilai absorban terbesar terdapat pada dosis $400 \mathrm{mg} / \mathrm{kg} \mathrm{bb}$, semakin menurunnya nilai absorban berarti konsentrasi karbon yang tinggal dalam darah mencit semakin sedikit. Hal ini memperlihatkan bahwa terjadi peningkatan aktivitas fagositosis pada masing-masing kelompok sediaan ekstrak uji.

Fagositosis adalah suatu mekanisme pertahanan yang dilakukan oleh sel fagosit, sel fagosit ini terdiri dari 2 jenis, yaitu fagosit mononuklear dan polimorfonuklear. Fagosit mononuklear contohnya monosit (didarah) jika berpindah ke jaringan menjadi makrofag. Fagosit polimorfonuklear adalah granulosit yaitu netrofil, eusinofil, basophil dan sel mast (dijaringan). Adapun proses fagositosis dimana mikroorganisme/partikel asing dikenali oleh sel fagosit, maka sel fagosit akan bergerak menuju partikel tersebut akan melekat dengan reseptor pada membran sel fagosit, membran sel fagosit tersebut akan menyelubungi seluruh permukaan partikel asing dan memasukkan nya ke dalam sitoplasma yang mirip seperti vakuola disebut fagosom. Selanjutnya, fagosom berikatan dengan lisosom yang berisi enzim penghancur seperti acid hydrolase dan peroksidase bergabung dengan fagosom membentuk fagolisosom. Sistem limfoid berfungsi untuk melindungi tubuh dari kerusakan akibat zat asing. Sel sel pada sistem ini dikenal dengan imunokompeten yaitu sel yang mampu membedakan sel tubuh dengan zat asing dan menyelenggarakan inaktivasi atau perusakan zat asing. Tugas limpa sangat penting, seperti berkontribusi pada produksi sel, fagositosis, dan pembangunan kekebalan. Peningkatan bobot hati dan limpa dapat mengindikasikan adanya peningkatan poliferasi sel-sel imun yang terdapat di dalam organ-organ tersebut (Kim, dkk., 2011).

\subsubsection{Indeks fagositosis}

Uji aktivitas fagositosis menggunakan metode carbon clearance merupakan gambaran sistem imun non spesifik pada proses fagositosis terhadap partikel asing didalam darah. Metode carbon clearance digunakan untuk mengukur aktivitas sel-sel fagosit untuk membunuh 
oragnisme patogen yang masuk kedalam tubuh. Fagositosis banyak digunakan sebagai parameter imunologi untuk mengevaluasi fungsi kekebalan tubuh. Penilaian kemampuan atau aktivitas fagositosis dalam mengeliminasi partikel karbon dinyatakan sebagai indeks fagositosis (Shukla, et al., 2009). Peningkatan indeks bersihan karbon menunjukkan perbaikan fungsi fagositik dari makrofag mononuklear dan imunitas non spesifik. Indeks fagositis setelah pemberian ekstrak etanol kulit batang dan buah attarasa ditunjukkan pada Gambar 2.

(a) EEKBA

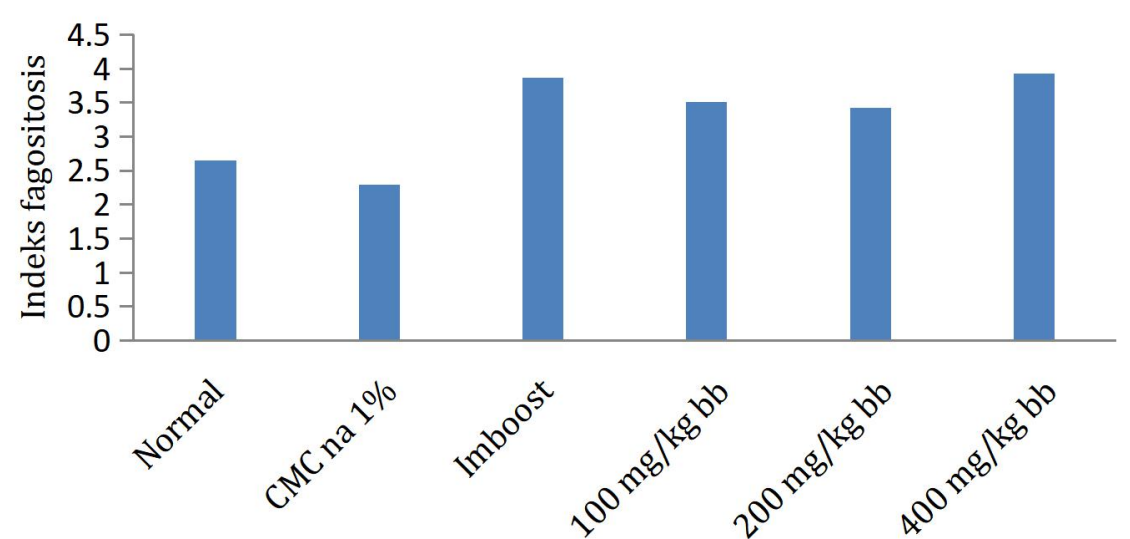

Kelompok perlakuan

(b) EEBA

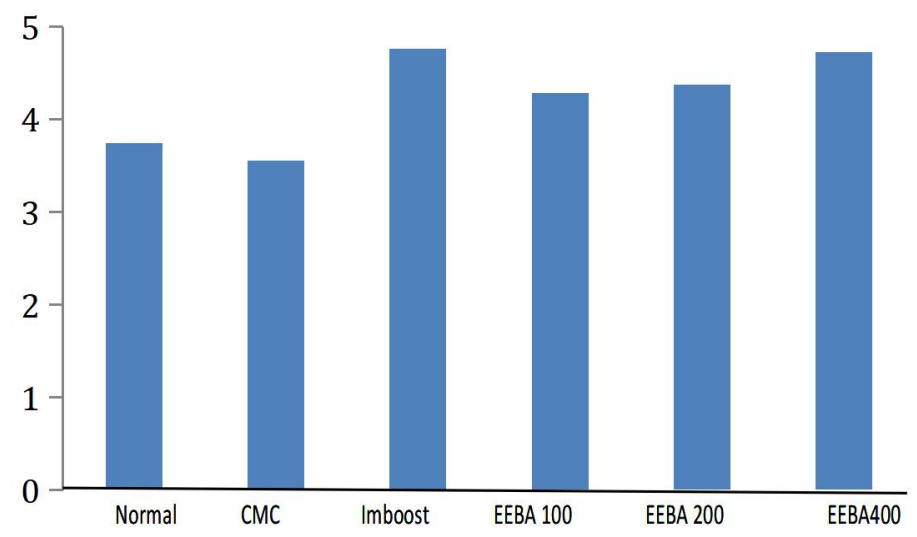

Gambar 2. Indeks fagositis

Pada Gambar 2 dapat dilihat Indeks fagositosis EEKBA and EEBA dosis 100, 200, dan 400 mg/kg BB yaitu 3,429 dan 4,289; 3,501 dan 4,375; 3,925 dan 4,732. Indeks fagositosis ekstrak dosis 100, 200, dan $400 \mathrm{mg} / \mathrm{kg}$ bb menunjukkan bahwa adanya hubungan peningkatan dosis dengan nilai indeks fagositosis, yaitu semakin besar peningkatan dosis maka nilai indeks fagositik semakin tinggi. Semakin meningkatnya indeks fagositik pada uji bersihan karbon 
menunjukkan adanya peningkatan aktivitas fagositosis dari makrofag dan peningkatan imunitas non spesifik. Keefektifan sel fagosit ditandai dengan peningkatan antibodi dan C3b komplemen, yang dimulai dari kecepatan pembersihan zat asing dari dalam darah (Ghaisas, et al., 2009).

\subsubsection{Indeks stimulasi}

Indeks stimulasi merupakan hasil perbandingan antara kelompok uji dengan kelompok kontrol. Suatu zat bersifat imunostimulan jika indeks stimulasi lebih besar dari 1 dan bersifat imunosupresan jika indeks stimulasi lebih kecil dari 1. Indeks stimulasi setelah pemberian ekstrak etanol kulit batang dan buah attarasa ditunjukan pada Gambar 3.

(a) EEBA

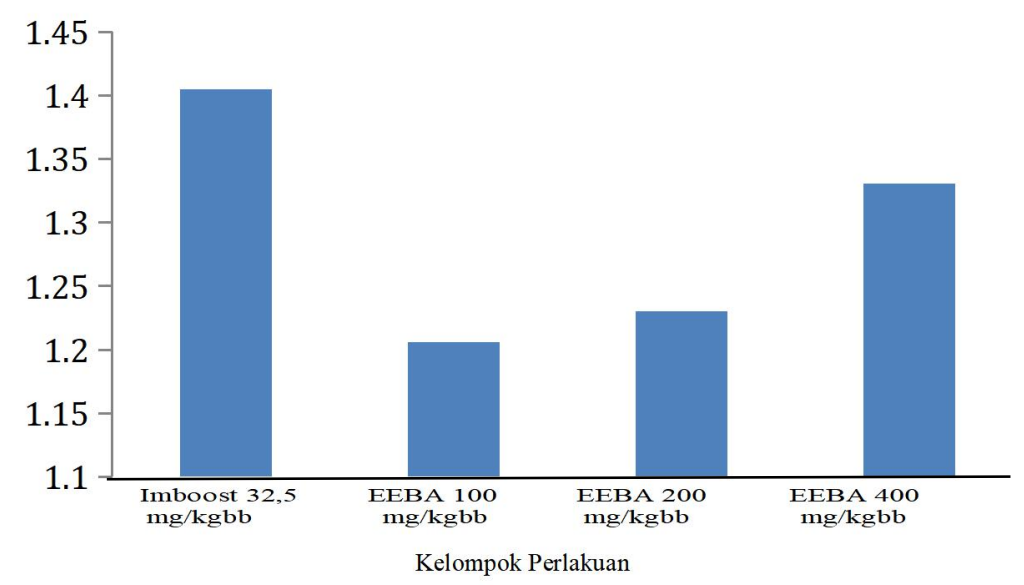

(b) EEBA

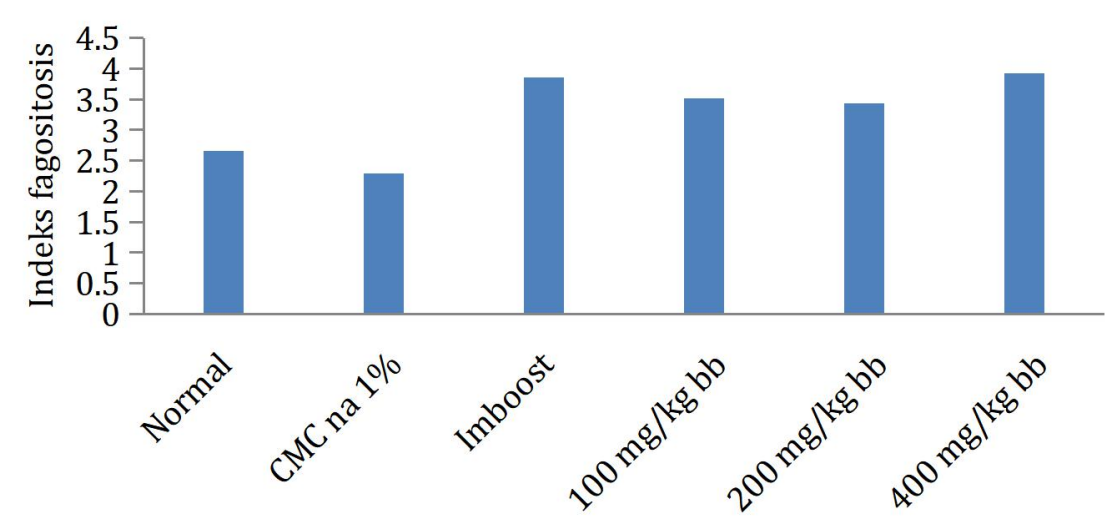

Gambar 3

stimulasi

Kelompok perlakuan

Indeks

Pada Gambar 3 dapat dilihat Indeks stimulasi EEKBA and EEBA dosis 100, 200, dan 400 Indeks stimulasi EEKBA and EEBA dosis 100, 200, dan $400 \mathrm{mg} / \mathrm{kg}$ BB yaitu 1,00 dan 1,20; 1,02 dan 1,23; 1,13 dan 1,33. Pemberian EEKBA and EEBA pada dosis 100, 200, dan $400 \mathrm{mg} / \mathrm{kg} \mathrm{BB}$ dapat meningkatkan aktivitas fagositosis pada mencit jantan dan terdapat perbedaan yang 
signifikan dengan CMC-Na 1\% dan kelompok normal $(\mathrm{p}<0,05)$. Indeks stimulasi ekstrak dosis 100, 200, dan $400 \mathrm{mg} / \mathrm{kg}$ bb menunjukkan bahwa adanya hubungan peningkatan dosis dengan nilai indeks stimulasi, yaitu semakin besar peningkatan dosis maka nilai indeks stimulan yang didapat semakin meningkat. Imunostimulator secara tak langsung berkhasiat mereaktivasi sistem imun yang rendah dengan meningkatkan produksi molekul perantara (messenger molecules), yaitu sitokin, yang fungsinya adalah sebagai mediasi dan mengatur sistem imun (Sasmito, 2017). Menurut Sasmito (2017) mengenai imonomodulator bahan alami bahwa senyawa flavonoid dapat meningkatkan sistem kekebalan tubuh hingga mampu menangkal serangan virus, bakteri atau zat asing lainnya, dengan cara meningkatkan aktivitas dari makrofag yang ditunjukkan dengan meningkatnya kemampuan fagositosis, aktivitas enzim lisosomal, serta memodulasi pelepasan nitric oxide oleh makrofag. Senyawa flavonoid dapat bekerja terhadap limfokin (interferon $\gamma$ ) yang dihasilkan oleh sel T sehingga akan merangsang sel-sel fagosit untuk melakukan respon fagositosis .

Efek suatu bahan sangat erat kaitannya dengan senyawa kimia yang terkandung dalam bahan tersebut. Mekanisme imunostimulan pada buah attarasa kurang lebih sama seperti mekanisme pada tumbuhan yang mengandung senyawa ini seperti dijelaskan diatas, yaitu memiliki efek imunostimulasi pada monosit, makrofag, natural killer cell, dan dendrit cell dengan meningkatkan aktivitas IL-2, proliferasi dan aktivasi limfosit T. Proliferasi limfosit menyebabkan sel Th1 teraktivasi. Kemudian sel Th1 yang teraktivasi akan mempengaruhi IFN ${ }^{\gamma}$ yang dapat mengaktifkan makrofag (Sasmito, 2017).

\section{Kesimpulan}

EEKBA dan EEBA mempunyai aktivitas imunomodulator yang bekerja dengan meningkatkan sistem imun (imunostimulan).

\section{Daftar Pustaka}

Aldi, Y., Nisya, O., dan Handayani. (2013). Uji Imunomodulator Beberapa Subrafraksi Ekstrak Etil Asetat Meniran Pada Mencit Jantan Dengan Metode Carbon Clearance. Prosiding Seminar Nasional Perkembangan Terkini Sains Farmasi Dan Klinik III

Azizah, M., Wiwik, W., Ema, R., S. (2017). Efek Imunomodulator Ekstrak Etanol Kulit Buah Nanas Terhadap Mencit Putih Jantan Dengan Metode Bersihan Karbon. Jurnal. Sekolah Tinggi Ilmu Farmasi Bhakti Pertiwi. Palembang

Ditjen POM. (2000). Parameter Standar Umum Ekstrak Tumbuhan Obat. Cetakan Pertama. Jakarta: Departemen Kesehatan RI. Hal. 10-11.

Faradilla, M., Maria, I, I. 2014. Efek Imunomodulator Polisakarida Rimpang Temu Putih (Curcuma Zeodoaria (christni) Roscoe). Jurnal Ilmu Kefarmasian Indonesia

Ghaisas, M.M., Shaikh, S.A., dan Deshpande, A.D., 2009, Evaluation of the 
Immunomodulatory Activity of Ethanolic Extract of the Stem Bark of Bauhinia variegata Linn., International Journal of Green Pharmacy, 70- 74, Department of Pharmacology, Institute of Pharmaceutical Scienceand Research, India.

Kim, K. L., Shin, K, S., Jun, W. J., Hong, B. S., Shin. D.H dan Cho, H. Y, (2011). Effectts of Polysaccharides from Rhizomes of Curcuma on Macrhopag Funchions. Browser Biotecnology. 65 (II): Halaman 2377.

Kurniaty, R., Dida, S., Kurniawaty, P., P., Aam, A. 2014. Kilemo (Litsea Cubeba L Persoon). Bogor: Kementrian Kehutanan

Linsentia, N., A. 2011. Aktivitas Imunomodulator Ekstrak Daun Kemangi Terhadap Mencit Jantan Dengan Metode Carbon Clearance Dan Neutrophilma adhesion. Universitas Sanata Dharma. Yogyakarta.

Rahman, H., Yufri, A., dan Elda, M. 2016. Aktifitas Imunomodulator Dan Jumlah Sel Leukosit Dari Ekstrak Kulit BUah Naga Merah Pada Mencit Jantan. STIFARM. Padang.

Sasmito, E. (2017). Imunomodulator Bahan Alami. Yogyakarta: Rapha Publishing Hal 3,16

Shukla, S., Suresh, P.V., Pradeep, M, Jinu, J., dan Archana, M. (2009). Immunomodulatory Activities of the Ethanolic Extract of Caesalpinia bonducella Seeds. Journal of Ethnopharmacology: 125, Halaman 252-256

Tambusai, N., A. 2018. Uji Efek Imunomodulator Ekstrak Daun Afrika Terhadap Aktivitas Fagositosis Sel Imun Pada Mencit Jantan Dengan Metode Karbon Klirens. Universitas Sumatera Utara. Medan 